International Journal of English Literature and Social Sciences
Vol-6, Issue-3; May-Jun, 2021

Peer-Reviewed Journal

\title{
Relevance of Chitra Benerjee Divakaruni's Palace of Illusions
}

\author{
Anurupa Ghosh
}

Department of English, Calcutta University, Kolkata, India

Received: 11 Feb 2021; Received in revised form: 25 Apr 2021; Accepted: 11 May 2021; Available online: 27 May 2021 (C)2021 The Author(s). Published by Infogain Publication. This is an open access article under the CC BY license (https://creativecommons.org/licenses/by/4.0/).

\begin{abstract}
A prolific writer of Indian writing in English, Chitra Banerjee Divakaruni has always aimed at giving voices to female characters in her novels like MISTRESS OF SPICES, SISTERS OF MY HEART, PALACE OF ILLUSIONS and many more. Writing in a Postmodern world where women issues are still relevant though different from the medieval times, she aims at creating fiction which all women can relate to. Feminism as a movement should not lose its significance even in this Postmodern society especially in a country like India which is yet to set itself free from the bars of age-old prejudices related to the existence of a woman; as Simone De Beauvoir speaks about it in her renowned work THE SECOND SEX arguing that women are socially conditioned to assume the role of a 'woman' in stereotypical terms.
\end{abstract}

Keywords-Patriarchy, Postmodernity, Protofeminist, Society, Womanhood.

\section{INTRODUCTION}

In this paper I would like to focus on Chitra Banerjee Divakaruni's 2008 novel PALACE OF ILLUSIONS centering round the life of Draupadi, depicted as a protofeminist questioning the norms of her society that is severely patriarchal." From a feminist perspective, when we interpret texts or anything else, the way we deal with our subjectivity is not to try to avoid it but to be aware of it as possible..." (Lois Tyson 95). Growing up with the stories of Mahabharata set in the Third Age of Man, Divakaruni picks up such a character which almost all Indian women can relate to. She has successfully shaped the life of the Princess of Panchaal such that it becomes extremely relevant even in the lives of Postmodern women. Dr SG Puri writes "Divakaruni in her novel THE PALACE OF ILLUSIONS talks of the social conditioning of a woman who descends her positioning in the cultural paradigm. She also talks of the significance of cultural scripts, which provokes a woman to negotiate her with space created through undergoing agency. The agency helps the society to have desired result" (1).

The novel begins by Panchaali (princess of the kingdom of Panchaal) recalling the events leading to her birth through the mouth of her Dhai Ma who calls her the "Girl Who Wasn't Invited" (Divakaruni 1), as she fancies different names which could be attributed to her. Living in today's world women feel equally unwanted as Panchaali did at the time of her birth when her father held out his arms only for her brother Dhristadyumna when she too came out of the holy fire beside her brother, destined to "change the course of history" (Divakaruni 5). Even today when practices like female foeticidehavebeen abolished, many Indian parents still showcase their unwelcoming attitude towards a female child compared to a male one who is expected to fulfill the dreams of their parents just as King Drupad wished for a male child to instrumentalize his revenge. When Dhai Ma says about King Drupad, "He could barely hold up his head, but of course he wouldn't remove the monstrosity of a crown that no one has ever seen him without -not even his wives, I've heard, not even in bed" (Divakaruni 2), it implies the male ego which is all the same down the ages.

The next issue which perhaps is all the more pertinent in our lives is our complexion. From people judging us based on our skin colours to the different fairness creams available in the market, one's complexion holds more 
significance than her personality even in a Postmodern society. Panchaali too is a victim of colorism as she says "In a society that looked down its patrician nose on anything except milk-and-almond hues,this was considered most unfortunate, especially for a girl" (Divakaruni 8). Nevertheless, under the guidance of Krishna, Panchaali does not consider this as her drawback when she confidently holds "I, too, am beautiful, I told myself, ...Overnight, I who had been shunned for my strangeness became a celebrated beauty!" (Divakaruni 9-10). In R K Narayana's Indian Epics Retold, Yudhisthir describes Panchaali as " the goddess Laxmi herself, in stature, grace and complexion..." (260). However, Divakaruni"s portrayal of Panchaali makes her phenomenal yet relatable. She is no less than any intelligent women to point out how Dhri was channelizing his life for an age-old revenge that her father seeked through him rather than emancipating himself, living a mechanical life. Aren't you giving up your entire life to get King Drupad what he wantssenseless though it is?" (Divakaruni 19). This brings us to another harsh reality of our lives as men too are subject to societal pressure with or without realizing; aissue that Mahesh Dattani takes up in his play DANCE LIKE A MAN.

Panchaali also recalls taking lessons from behind the curtains while Dhri was being tutored and how it has been a challenge for her in a society that could not even think of women education. The teacher rebuked at her prompting answers to her brother alongside her father,brother and DhaiMa who thought "... they were making me too hardheaded and argumentative, too manlike in my speech" (Divakaruni 23). The fact that women can voice their own opinion is still unacceptable today especially when we try to break out of bars of male suppression. She also rejects the notion of polygamy in a society where multiple marriages were customary, though ironically, by saying “ My husband won't take up another wife- I'll make him promise that before I marry him!" (Divakaruni30).

Sikhandi is one of the rebellious figures who chooses to undertake a life totally different from that which is expected of a stereotypical female. She decides to live her life on her own terms just as any other Postmodern woman should. Even in her previous birth she dares to question the set norms about the purity of a woman by stating "...If someone grasps my hands against my will, how does that make me his? Isaid, I'm the one who decides to whom I belong". (Divakaruni 48). This is something very much relevant in our day where we see a persisting rape culture that allows men to treat women as some property who easily gets contaminated even if it is against her will. DE Beauvoir writes " No biological, psychical, or economic destiny defines the figure that the human female takes on in society; it is civilization as a whole that elaborates this..." (293).Sikhandi's embracing of the forbidden garland is symbolic of acting against the rules that the society has set for women. Panchaali's reading of the scriptures amongst a group of girls who were engaged in so-called feminine activities portrays the kind of determination that we all require in order to make ourselves leap the boundaries of patriarchy. "But I was determined to learn what a king was supposed to know. (How else could I aspire to be different... How else could I be powerful in myself?)" (Divakaruni 54).

When Panchaali wanted to see the portrait of her prospective mother-in-law she was instead sent the portrait of Gandhari, Arjun's aunt, that too wasan ill-executed one, small in size, quite inferior to the ones of the Kings. This hints at the value that the world holds of women in physical terms and once it perishes, she loses significance just like Gandhari or any other queen. It is very much prevalent in the film industry where we get to see heroines romancing heroes almost double their age while the women lose their importance in the industry as soon as they start growing old, pointing at their objectification in a male dominated world. "Perhaps there wasn't much demand for the pictures of women, once they were married off, even if they were queens" (Divakaruni 75). The day her mother-in-law decided to marry her off to all the five brothers instead of just Arjun, she was angered but a faint streak of admiration appeared in her face for Kunti, who despite being a woman held such control over her sons such that they could not even deny her. Lying in the hut she aspires to build herself a palace instead of dreaming of her in-law's estate, teaching us an important lesson about being independent and careeristic. At her father's palace when her fate was being decided even then she was helpless to take decisions about her own life as her guardians were only thinking of their honour and not of her life: "But I was distressed by the coldness with which my father and my potential husband discussed my options, thinking only of how these acts would benefit-or harmthem" (Divakaruni 118). Polygamy was common those days for a man and having to experience that as a woman was not delightful to her because it was not her choice and even the boon of virginity was somehow designed for the men's benefit, she thought. At her in-law's kingdom she longed for an intellectual conversation but the palace did not allow such liberty for women. Even today in some households women are kept away from decision-making even if it is about their own life as if we are only meant to guard the honour of the family through selfless sacrifices and having to choose only for ourselves seems a crime.

At Khandav,Panchaali played a crucial role in building the kingdom of the Pandavas and not merely reduced 
herself to a pleasure object meant to caress with. She proved her worth as a result of which even if her husbands had other wives she remained special to them, not letting others to disrate her. In a male dominated society it is important for us to establish our significance rather than just ask for it. Just like Panchaali we too must endeavour to prove our worth: "I'd played a crucial role in bringing then to their destiny... If they were pearls, I was the gold wire on which they were strung" (Divakaruni 151). Though, at first she was rude towards the other wives of her husbands, she eventually let go off her anger and became more friendly with them, teaching us an important lesson on how women should stand by one another because they too were victims of patriarchy. Regarding the afterlife of a woman she too had an opinion although she kept it to herself. Unlike the tutor of Dhri, she thought, “...if lokas existed at all, good women would surely go to one where men were not allowed so that they could be finally free of male demands" (Divakaruni 155). Then came the fateful day of the dice game where Yudhisthir had lost Panchaali. Enraged and disheartened, she hurled curses at the princes and people of Hastinapur that would lead to the Great War, changing the course of history. From that day she knew that there was no one to guard the honour of a woman in a male dominated world; one has to stand for herself: "The wife is the property of the husband, no less so than a cow or a slave...the laws of men would not save me". (Divakaruni 190-91) Objectification of women is no less prevalent today than in those days. Women are continually involved in a struggle to safeguard their dignity; knowingly or unknowingly as Maya Angelou saidthat each time a woman stands up for herself, without knowing it possibly, without claiming it, she stands up for all women. The image of Hidimba, as Panchaali recalls brings to our mind the figure of emancipated womanhood.

When the War was finally over Panchaali grieved the sight of the widows who hurled abuses at her husbands and resolved to bulid a separate woman's court where their grievances would be addressed. And soon after that Hastinapur was a prosperous town where women took the responsibilities of their own families and there was a flourishing woman's market too: "Hastinapur remained one of the few cites where woman could go about their daily lives without harassment" (Divakaruni 325). This is something we all dream of; a place where women are absolutely free to pursue whatever they can without criticism. Panchaali finally undertook the last journey along with her husbands and despite all the hardships she remained adamant to embark on it, as she asserts, "Perhaps that has always been my problem, to rebel against the boundaries society has prescribed for women" (Divakaruni 342).

\section{CONCLUSION}

Divakaruni's portrayal of Panchaali truly reflects the vision with which she had chosen a character from the ancient times while writing about the concerns of Postmodernity. With all her flaws, Divakaruni'sPanchaali mirrors the principal thoughts that one would go through in a world laden with injustice towards woman, finding itsaptness.

\section{REFERENCES}

[1] Beauvoir, Simone De, "The Second Sex", Penguin Publisher, 1972; p293

[2] Divakaruni, Chitra Banerjee "The Palace of Illusions" Picador Publication, 2008, pp1-342.

[3] Dr Puri, S G "Replication of the Cultural Scripts in Chitra Banerjee Divakaruni's The Palace of Illusions", Contemporary Literary Review India 2:3, 2015, p1.

[4] Narayan, R K, "The Indian Epics Retold, Penguin Books India, 1995, p260

[5] Tyson Lois, "Critical Theory Today", Routledge, New York; 2006, p95 